\title{
Karens-The Low Profile Migrants of Andaman Islands
}

\author{
Anita Banerjee $^{1^{*}}$, Kripa Mondal ${ }^{2}$ \\ 1. Andaman Law College, Port Blair, Andaman and Nicobar Islands, India \\ 2. Malati Krishna Trust, A Local NGO, Andaman and Nicobar Islands, India
}

How to cite this paper: Banerjee, A., \&, Mondal, K. (2017). Karens-The Low Profile Migrants of Andaman Islands. The Educational Review, USA, 1(2), 34-38. http://dx.doi.org/10.26855/er.2017.02.003

*Corresponding author: Anita Banerjee, Assistant Professor, Andaman Law College, Port Blair, Andaman and Nicobar Islands, India.

\begin{abstract}
Migration is a process whereby people leave their place of origin and settle down either within the national boundaries or to an alien land. Around 3\% of the world's populations are international migrants. The present study focuses on the rather low profile migrants "the Karen Community" into Andaman Islands and traces their contribution towards the economic development of the Islands. The study concludes that in-migration has contributed to the overall progress of the islands and they can be called as the earliest settlers to this part of Andaman.
\end{abstract}

\section{Keywords}

Karen, Migration, Economy, Education, Myanmar

\section{Introduction}

Migration is a process whereby people leave their place of origin and settle down either in another place within the national boundaries or in an alien land. Human migration is one of the most important aspects of social science. Study of human migration is gaining importance day by day due to complexities of human life, changing socio-economic and political conditions. Around 3\% of the world's populations are international migrants. Several theories of migration have been floated ever since the first pioneering theory of migration given by Raveinstein's laws of migration as early as 1885 (Reveinstein, 1889). If one were to look at the migration pattern in the Indian context, most migration streams are either inter-state or intra-state migration.

Karen community from Myanmar can be credited to be the first group of migrants to Middle Andaman, hence even more important, because their presence and persistent hard work gradually brought about winds of change, to the largest district of Andaman and Nicobar islands that is the island of North and Middle Andaman which is now the 614th district among a total of 640 districts in India.

\section{Migration and Andaman Islands}

The earliest original inhabitants of these islands were the Andamanese belonging to the Negrito race. "Negrito " is the name given to people hailing from South-East Asia sharing some common physical characteristics; hence they are known by a common name. They were spread in different islands. It was with the annexation and subsequent colonization of these pristine Islands in 1858, settlement of people started. Andaman and Nicobar Islands, if one were at liberty to say would be called a land of immigrants. Andaman and Nicobar Islands present a unique case wherein initially it was a penal settlement later on migration of people brought these Islands into prominence. Though the original inhabitants are of the Negrito race, it was due to the 
coming of migrants, the process of development was initiated. Many communities have migrated to the Andaman Islands from various parts of the country and made Andaman their home. Bengalis, Tamils, Ranchi, Telegu, Malayali migrants are often talked about and discussed. Karens are a very low profile community confined to North and Middle Andaman district.

\section{Who are the Karens?}

Karens are the tribes belonging to the Mongoloid race; they were called by the name "Karen" by the British rulers, whereas they named themselves as "Pwakanyaw" which translated in English means "quiet and peace loving persons".

\section{Origin of Karens}

Contrary to what is normally believed about Karens is that they are migrants from erstwhile Burma, but as per historical records they are originally from Mongolia. They belong to the Mongoloid race, due to the tyrannical rule of the then kings, forced these peace loving people to move southwards to east of Turkistan and China between B.C. 2017-2013. This was also not meant to be their final place of settlement, because they again shifted their place of residence to Tibet in B.C. 1864, Thailand, Cambodia, and Vietnam. Gradually they migrated towards the hilly tracts of Burma.

In 1886 Burma was declared a part of British India. Had it not been for Dr. H. I. Marshall, who was the Principal of Karen Theological Seminary at Insein in Rangoon-migration of Karen laborers, would not have taken place. In order to meet his cousin Col.Ferrar who was the then chief commissioner of Andaman and Nicobar Islands, Dr. Marshall visited the Islands. It was on his sojourn to the Islands his cousin (The Commissioner) informed Dr. Marshall about the shortage of laborer in the Andaman and hence requirement of laborers in Andaman Islands for clearing forests. He also informed Dr. Marshall about the British Governments generous settlement schemes under which migrants would be provided with free of cost lands along with free ration for a year. However this did not lead to the immediate migration of laborers. Dr. Marshall returned to Rangoon and published in a newspaper titled HsahTuGaw, (which literally means the "morning star") what was told to him by his cousin regarding the requirement of laborers who would be asked to perform manual labor, which included felling of trees, cleaning of forests as well as taking care of the elephants in Andaman Islands. Again it was a Karen Priest, Rev Lugyi who read the news paper and visited the Islands to make himself sure about what he had read. He was quite satisfied after the visit and under his stewardship the first batch of Karens (13 families) touched the soils of these Islands in April1925. This was followed by the second batch of migrants comprising 50 families in 1926. Initially, Karens were brought to Carlo Islands, also known as Bonnington where they stayed for 10 days, later they were permanently settled in the village named Webi which means the "hidden place". Karens were known as the early settlers living in isolated villages, happened to be the only permanent settlers of North Andaman since 1925.

The present study was carried out in order to examine the migration of Karen community in the context of Raveinstein's law of migration and Everett Lees theory of Push and Pull factors of Migration. (The study also seeks to trace the trajectory of their contribution towards the economic development of the Islands. For the purpose of study, qualitative approach was adopted, other than secondary sources of information such as books and articles were also extensively used. Since the focus of the study was on the contribution of Karen community towards development, a sample of 100 respondents were randomly chosen.

\section{Reason for Migration of Karens in Andaman Islands}

Migration of Karen community into these Islands can be traced back to the pre independence era. Among the pioneers of the theories of migration Raveinstein's name still remains unparallel in the studies on migration. Though with changing times and complexities of modern living the causes of migration have also acquired new dimensions yet one of the reasons attributed to migration by the laws of migration (as given by Raveinstein) still happens to be quite valid and that pertains to dominance of 
economic activities, as the reasons for migration, particularly the desire inherent in most men to "better" themselves in material respects. It is not to seek pleasure that people take to migration, rather it is the circumstances which drives them towards this end. Adam Smith has rightly remarked that of all luggage, man is the most difficult to transport. Hence, the migration of Karens to the Islands was certainly to "better" their economic conditions.

Dr. Marshall ( Principal of Karen Theological Seminary at Insein in Rangoon) after having learnt from his cousin regarding the requirement of poor, landless laborers who were in need of work and also about the promise of allotting lands to the immigrants conveyed it to the Karens through the local news papers, so that set in motion the process of migration. In addition the promise of free ration for a year was also another strong reason for their migration.

Migration of the Karen tribes can also be viewed in the context of Everett Lee's theory of Push factors and Pull factors (Lee, 1975) which drive people from one country to another. Push factors are clearly the pitiable economic conditions and political unrest prevailing during that period. Since by their very disposition they were peace loving persons and as history has it they were never at peace, as they were troubled by the ruler while in China. Eventually when they settled in the hilly tracts of Burma but had to face several hardships, which meant living a perilous existence. There was widespread ethnic unrest at that time in Burma and Christian Missionaries close to the Karens were quite concerned. Their migration to the Islands cannot be categorically termed as forced labor migration; hence it was the unfavorable factors in their home country which pushed them to this Island. Pull factors are of course opportunity to own and cultivate lands in Andaman, also work as forest laborers and mahouts. In addition political condition at the time of migration of Karens was not conducive to peaceful living.

\section{Political condition at the time of migration of Karens}

At the time of migration of Karens, Islands of Andaman were going through a transformative phase in terms of being a solely a penal settlement to a move towards a more open place. The British colonizers were in need of laborers to clear forests. Karen population at the time of migration was extremely cautious about their behaviour with people of other communities whom they addressed as "Khlathu". They did not mingle with people of other communities. They almost lived a life of isolation. One of the reasons could be attributed to the fact that when penal settlement of convicts began in the Islands they had to face the wrath of the aborigines who were the original inhabitants of the Islands. Karens witnessed three administrative changes ever since they landed in these Islands. When they first migrated to Andaman, it was under the British rule, that is roughly during 1925-1942, thereafter for a brief period the Islands were ruled by the Japanese from 1942 to 1945, and again from 1947 onwards they became permanent Indian citizens.

\section{Present Status: Population}

Karens have come a long way since they ventured into this land of pristine beauty more than 80 years ago. The first batch of Christian Karens sailed in a ship and touched the coast of Mayabunder (which means port of illusion) in 1925. Initially around 250 to 300 Karens had migrated. Gradually due to opportunities and peaceful life, the process of migration into middle Andaman continued till the year 1947. Now their population stands at approximately 3000 . They are spread over a total eight villages, which are i) Deopur, ii) Lataw village iii) Lucknow village (earlier known as Burmadera). Later on in 1960's the next generation moved to Karmatang-IX and Karmatang-X villages, besides Webi: the first village they were settled in. All these villages fall under Mayabunder Tehsil. Some Karens were also allotted revenue lands; the name of this village is Borang. In the year 1970, Karens further spread to Diglipur Tehsil and occupied some forest land in Chipo village.

\section{Contribution to the Economy}

Contribution of Karen community towards the economic development of the economy of middle Andaman can be assessed in 
terms of their economic activities, including the types of occupation that they are engaged in. Though the options available are few, yet they can be broadly classified as primary, which includes besides agriculture, fishing. Major parts of middle And aman were under thick flat forest lands. Karens were skilled forest labors; therefore due to their inherent skills and adequate knowledge of flora and fauna, they were successful in transforming these forest lands to agricultural lands without many monetary and material resources. They have introduced a new variety of paddy known as "Burma Rice" which is reddish in color and fetches more price than the local variety. This and other varieties of paddy are grown both for subsistence as well as for the markets. Around $25 \%$ of the population is engaged in services (Government jobs) which range from blue collared jobs like Mahouts, forest labors to white colored jobs in the education department. The distribution of Karens according to their occupation is as follows:

Table 1. Occupational pattern of Karens.

\begin{tabular}{ll}
\hline Occupation & In Percentage \\
\hline Agriculture (including fishing) & 28 \\
Government jobs & 25 \\
Scuba Divers & 18 \\
Business & 11 \\
Others & 18 \\
\hline
\end{tabular}

Majority of the people are engaged in agriculture and allied activities, as is evident from the table. In the second category are included people who are working in government jobs. Around $18 \%$ of Karen men are rendering their services as scuba divers in Havelock Island. It is worth noting that since the year 2005 Karen community has been granted the status of OBC, though they are not quite happy with the status, as they wanted to be included in the tribal category. Nevertheless, their awareness has at least helped them to achieve the status of OBC.

Education: Level of literacy is not very high among the Karens. Fifteen percent of Karens opt for post graduation. Most of them $(35 \%)$ are satisfied with primary level of education. Though there is a primary school in all the 8 villages occupied by the Karens. Besides two villages have secondary and senior secondary schools. They are as follows:

Table 2. List of schools in Karen dominated areas.

\begin{tabular}{ll}
\hline Name of the village & Type of School \\
\hline Karmatang-9 & Primary School \\
Karmatang-10 & Sr. Secondary School \\
Deopur & Primary School \\
Lucknow & Primary School \\
Borong & Primary School \\
Chepo & Primary School \\
Webi & Secondary School and \\
& Carey Memorial School( Private) \\
\hline
\end{tabular}

The schools not only serve the needs and provide education to the Karens but also to the non Karen Children, This also indicates their involvement in the development of the Island. From 2016 onwards Karen language has been granted the status of third language in the school located at Webi.

\section{Cultural Development}

Karen migration has also simultaneously contributed to the cultural diversity of the Islands. Karen Cuisine like "Nappi" is also quite popular in the Islands. Karen form of dances, particularly the bamboo dance is represented as one of the main dance forms of Andaman \& Nicobar Islands. The older generation was also known for their handiwork (mainly those made out of bamboo), though now it is on the decline (Maruska, 2012). 


\section{Conclusion}

Migration of Karens to the Islands was not forced, they migrated in search of better opportunities and to that end they have been quite successful. The major conclusions drawn may be summarized in the following points

i. Migration can affect the host country in either way that is in a positive or negative manner. The study reveals that the migrating population has led to the development of middle Andaman. They can be called as earliest settlers of this part of Andaman to be followed by other settlers. In this context it would not be wrong to conclude that they survived in the face of hardships with little resources at their disposal, and made the place habitable. Thus, in-migration has helped and promoted the process of development.

ii. Now the question of whether the migrants themselves benefitted, through the process of migration: well the answer is certainly 'yes'. They are far better off than their counterparts who are constantly living under the threat of ethnic violence, insurgency and abject poverty in Myanmar.

iii. Culturally the Karens have further enriched the already diverse culture of these Islands.

iv. The present generation is gradually adopting the culture, food and other traits of people of other communities due to intercommunity marriages between them.

Thus, it is assimilation of people of different hues which go into the process of development of a hitherto uninhabited land, this is very true of these very low profile/ lesser known migrants of the Andaman Islands.

\section{References}

Andaman Chronicle. (2013). The Karen Tribes of Andaman Islands-Lest we Forget. Accessed March 8, 2013. http://www.andamanchronicle.net/, March 8, 2013

Edith, M. (2009). Island of Peace. The Irrawaddy, 17 (5).

Lee, E. S. (1975). A Theory of Migration. In Population Studies (ed.). Chicago: Rand Mcnally, Publishing Company.

Maruska S. (2012). Moving Subjects, Moving Objects, Transnationalism, Cultural Production\&Emotions, Chap. 6 (ed.). New York: Berghahn Books.

Reveinstein, E. G. (1889). The Laws of Migration. Journal of Royal Statistical Society, 52.

Sameera, M. (2004). The Karen-A Lesser Known Community of Andaman Islands (India). In Islands of the World VIII International Conference.

Tanvi, M. (2015). The Karen of Andaman Islands, Labor Migration, Indian Citizenship and Development of Unique Cultural Identity. University of Pennsylvania, Scholarly Commons.

Tiki Wiki CMS Groupware. (2016). Migration Push/ Pull Factors. Accessed January 9, 2016. http://lewishistoricalsociety.com/wiki2011/tiki-read_article.php?articleId=28. 